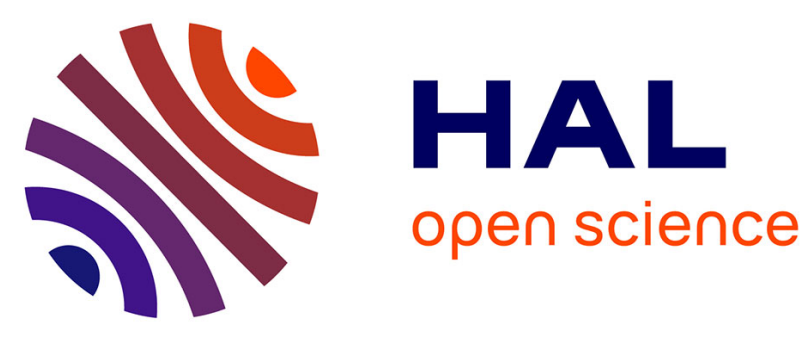

\title{
Effects of diet quality and dietary calcium on reproductive performance in Archachatina ventricosa (Gould 1850), Achatinidae, under indoor rearing conditions
}

Atcho Otchoumou, Mathilde Dupont-Nivet, Henri Dosso

\section{To cite this version:}

Atcho Otchoumou, Mathilde Dupont-Nivet, Henri Dosso. Effects of diet quality and dietary calcium on reproductive performance in Archachatina ventricosa (Gould 1850), Achatinidae, under indoor rearing conditions. 2th International Congress on Invertebrate Reproduction and Development (ICIRD), Aug 2010, Prague, Czech Republic. 10.1080/07924259.2011.588013 . hal-01019804

\author{
HAL Id: hal-01019804 \\ https://hal.science/hal-01019804
}

Submitted on 6 Jun 2020

HAL is a multi-disciplinary open access archive for the deposit and dissemination of scientific research documents, whether they are published or not. The documents may come from teaching and research institutions in France or abroad, or from public or private research centers.
L'archive ouverte pluridisciplinaire HAL, est destinée au dépôt et à la diffusion de documents scientifiques de niveau recherche, publiés ou non, émanant des établissements d'enseignement et de recherche français ou étrangers, des laboratoires publics ou privés. 
This article was downloaded by: [Inra], [Mathilde Dupont-Nivet]

On: 11 October 2011, At: 06:33

Publisher: Taylor \& Francis

Informa Ltd Registered in England and Wales Registered Number: 1072954 Registered office: Mortimer House, 37-41 Mortimer Street, London W1T 3J H, UK

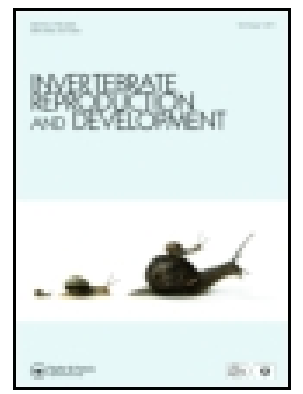

\title{
Invertebrate Reproduction \& Development
}

Publication details, including instructions for authors and subscription information:

http:// www. tandfonline.com/loi/tinv20

\section{Effects of diet quality and dietary calcium on reproductive performance in Archachatina ventricosa (Gould 1850), Achatinidae, under indoor rearing conditions}

\author{
Atcho Otchoumou ${ }^{a}$, Mathilde Dupont-Nivet ${ }^{b} \&$ Henri Dosso ${ }^{c}$ \\ ${ }^{a}$ Laboratoire de Biologie et Cytologie Animales, UFR des Sciences de la Nature, Université \\ d'Abobo-Adjamé, 26 BP 623 Abidjan 26, Côte d'Ivoire \\ ${ }^{b}$ Institut National de la Recherche Agronomique, UMR 1313, Génétique Animale et Biologie \\ Intégrative, Domaine de Vilvert, Equipe GENAQUA, 78352 J ouy en J osas Cedex, France \\ ${ }^{c}$ Centre de Recherches en Ecologie (CRE), Université d'Abobo-Adjamé, 52 BP 801 Abidjan \\ 52, Côte d'Ivoire
}

Available online: 30 J un 2011

To cite this article: Atcho Otchoumou, Mathilde Dupont-Nivet \& Henri Dosso (2011): Effects of diet quality and dietary calcium on reproductive performance in Archachatina ventricosa (Gould 1850), Achatinidae, under indoor rearing conditions, Invertebrate Reproduction \& Development, DOI: 10.1080/ 07924259.2011.588013

To link to this article: http:// dx. doi.org/ 10.1080/07924259.2011.588013

\section{firist}

\section{PLEASE SCROLL DOWN FOR ARTICLE}

Full terms and conditions of use: http://www.tandfonline.com/page/terms-and-conditions

This article may be used for research, teaching, and private study purposes. Any substantial or systematic reproduction, redistribution, reselling, loan, sub-licensing, systematic supply, or distribution in any form to anyone is expressly forbidden.

The publisher does not give any warranty express or implied or make any representation that the contents will be complete or accurate or up to date. The accuracy of any instructions, formulae, and drug doses should be independently verified with primary sources. The publisher shall not be liable for any loss, actions, claims, proceedings, demand, or costs or damages whatsoever or howsoever caused arising directly or indirectly in connection with or arising out of the use of this material. 


\title{
Effects of diet quality and dietary calcium on reproductive performance in Archachatina ventricosa (Gould 1850), Achatinidae, under indoor rearing conditions
}

\author{
Atcho Otchoumou $^{\mathrm{a} *}$, Mathilde Dupont-Nivet ${ }^{\mathrm{b}}$ and Henri Dosso ${ }^{\mathrm{c}}$ \\ ${ }^{a}$ Laboratoire de Biologie et Cytologie Animales, UFR des Sciences de la Nature, Université d'Abobo-Adjamé, 26 BP 623 \\ Abidjan 26, Côte d'Ivoire; ${ }^{b}$ Institut National de la Recherche Agronomique, UMR 1313, Génétique Animale et Biologie \\ Intégrative, Domaine de Vilvert, Equipe GENAQUA, 78352 Jouy en Josas Cedex, France; ${ }^{C}$ Centre de Recherches en \\ Ecologie (CRE), Université d'Abobo-Adjamé, 52 BP 801 Abidjan 52, Côte d'Ivoire
}

(Received 13 September 2010; final version received 6 May 2011)

Ten month old Archachatina ventricosa (Gould 1850) snails with an average body weight of $53.37 \mathrm{~g}$ and $68.50 \mathrm{~mm}$ shell length were fed two vegetable $\left(R_{1}\right.$ and $\left.R_{2}\right)$ and four concentrated diets $\left(R_{\mathrm{T}}, R_{3}, R_{4}\right.$ and $\left.R_{5}\right)$ with variable calcium content $(0.83 \% ; 4.65 \% ; 06.84 \% ; 12.01 \% ; 14.02 \%$ and $16.01 \%$, respectively) in order to determine the effects of diets and dietary calcium on reproductive performances. Concentrated diets stimulated reproduction while these events were reduced by vegetable diets. The results showed that the characteristics of the eggs (mean weight, largest diameters and smallest diameters of eggs) increased with the dietary calcium increment. In general, reproductive parameters decreased with dietary calcium increment excepted diet $R_{5}$. However, the best reproductive performance was obtained with a mixture of a pilot diet $\left(R_{\mathrm{T}}\right)$ and a calcium rich, concentrated flour $\operatorname{diet}\left(R_{5}\right)$.

Keywords: Archachatina ventricosa (Gould 1850); dietary calcium; reproduction

\section{Introduction}

Large edible terrestrial gastropods ( $c a$. $600 \mathrm{~g}$ live weight and $15 \mathrm{~cm}$ shell length approximately) occur naturally in hygrophilous forests of Côte d'Ivoire in West Africa. These common and conspicuous molluscs belong to three species Achatina achatina (Linnaeus) (600 g live weight and $15 \mathrm{~cm}$ shell length); Achatina fulica (Bowdich) (150 g of live weight and $10 \mathrm{~cm}$ of shell length) and Archachatina ventricosa (Gould) (300 g of live weight and $12 \mathrm{~cm}$ of shell length). The first two species are traditionally consumed while the third is less because of many taboos. However, A. ventricosa (Gould) is very rich in protein, minerals and particularly in iron (Aboua 1995; Aboua and Boka 1996; Otchoumou et al. 2010) and constitute a potentially valuable source of animal proteins and iron for rural human populations. Many attempts of production in Cote d'Ivoire have been unsatisfactory because of the use of wrong wild or cultivated plants in the diet (Otchoumou et al. 2003a, 2003b, 2004a, 2005a). Most often, consumed and/or marketed snails A. ventricosa (Gould) are collected in the wild during the rainy seasons (Ebenso 2002; Ekoué and KuéviAkoué 2002; Kouassi et al. 2007b). Artificial culture is necessary, therefore, to make up for seasonal deficits of snails and to relieve the species from pressures such as result from the destruction of the forests, bush fires, use of the pesticides and harvesting (Otchoumou et al. 1989-1990; Osemeobo 1992). The success of the breeding needs a specialized diet able to accelerate maturity, abundant layings and a better hatching rate. In snail diets, calcium is an important nutrient required for shell construction and egg envelope development (Ngowsiri et al. 1989). This study was carried out at the experimental farm of the University of Abobo-Adjamé in Abidjan in Côte d'Ivoire and lasted 6 months. We report the effects of vegetable and concentrated diets and dietary calcium on the reproductive performance in A. ventricosa (Gould) under indoor rearing conditions in order to contribute to the development of the culture of this species for human consumption and for its conservation.

\section{Materials and methods}

Animals

Six hundred snails of the species $A$. ventricosa (Gould) of $36.4 \mathrm{~g}$ mean body weight and $6 \mathrm{~cm}$ mean shell length were used (Figure 1). The adult size of this snail species (Giant African land snails) was $580 \mathrm{~g}$ and $147 \mathrm{~mm}$, respectively for body weight and shell length in its natural habitat. Their age, estimated from linear

\footnotetext{
*Corresponding author. Email: albertameri@yahoo.fr
} 


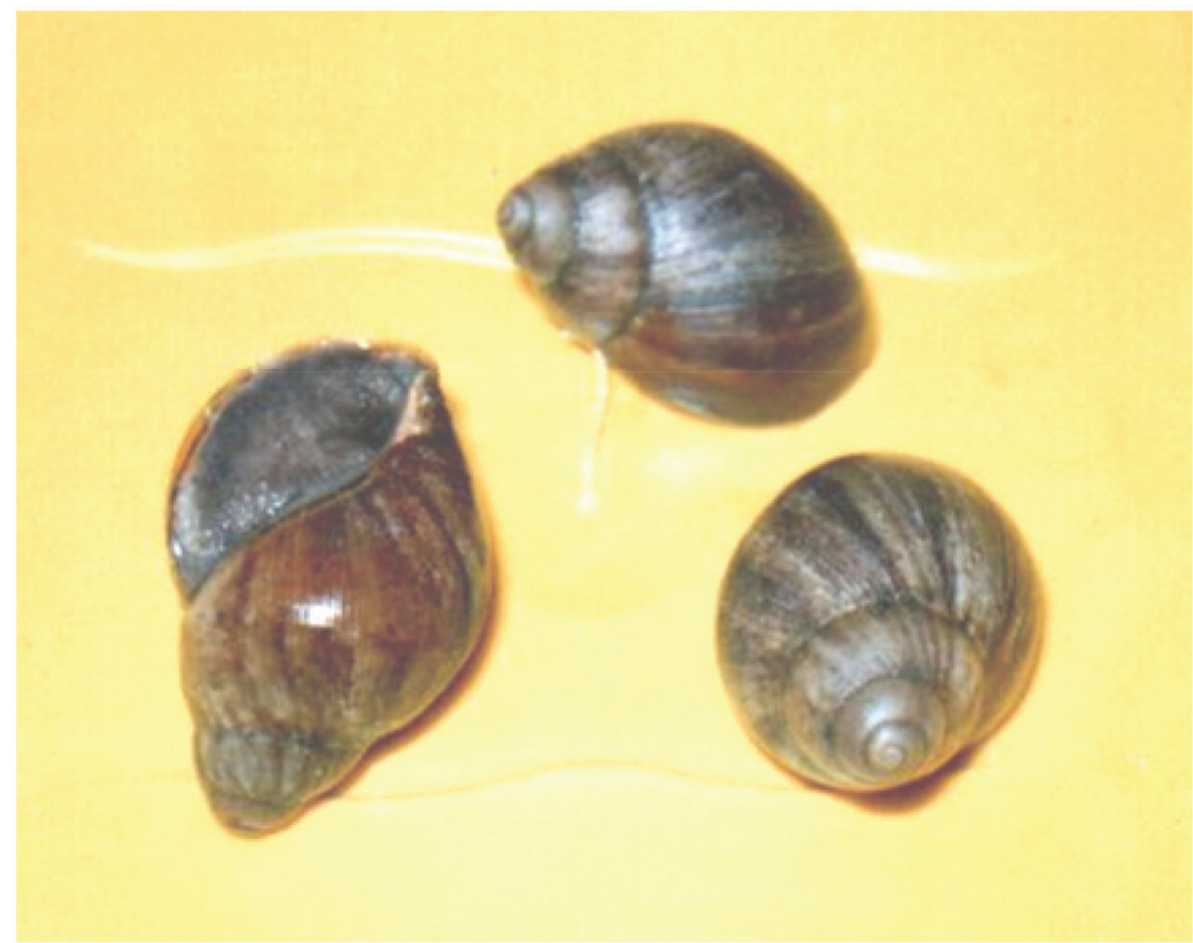

Figure 1. Individuals of A. ventricosa (Gould 1850).

growth curves (Hodasi 1979; Zongo et al. 1990; Otchoumou et al. 2003b) was approximately 10 months. They were collected in the forests of southwest Côte d'Ivoire from an area of approximately 2 ha and were acclimatized in the laboratory for 2 weeks prior to experimentation under the following ambient conditions: temperature and average relative humidity of $26 \pm 1.3^{\circ} \mathrm{C}$ and $82.9 \pm 1.2 \%$, respectively, with a $12 \mathrm{~L}: 12 \mathrm{D}$ photoperiod. They were nourished with fresh leaves of papaw tree (Carica papaya (Caricaceae)) during this period.

\section{Diets}

After 2 weeks of laboratory habituation, the snails were assigned to six groups, each fed on a different diet:

- two vegetable diets consisting either of $50 \%$ of fresh leaves of Lactuca sativa (Apiaceae) and $50 \%$ of fresh leaves of Brassica oleracea (Brassicaceae) $\left(R_{1}\right)$ or of $50 \%$ of fresh leaves of Laportea aestuans (Urticaceae) and 50\% of fresh leaves of Phaulopsis falcisepala (Acanthaceae) $\left(R_{2}\right)$. An inventory of wild and cultivated plants consumed by $A$. ventricosa (Gould) showed that this snail species prefers fresh leaves of $L$. sativa (Apiaceae) and B. oleracea (Brassicaceae) for cultivated plants and fresh leaves of L. aestuans (Urticaceae) and P. falcisepala (Acanthaceae) for the wild forest plants (Otchoumou et al. 2004a, 2004b; 2005a, 2005b).

- Three concentrated diets $R_{3}, R_{4}$ and $R_{5}$ with variable calcium contents $(12.01 \% ; 14.02 \%$ and $16.01 \%$, respectively) and a pilot diet $\mathrm{R}_{\mathrm{T}}$, $6.84 \%$ calcium content already used at the Central Laboratory of Animal Nutrition for A. achatina (Linné) growth (Zongo et al. 1990; Otchoumou et al. 2004b).

The composition of diets was checked by chemical analysis (AOAC 1984). The results are presented in Table 1.

\section{Breeding and collection of the parameters of reproduction}

Snails were reared in wooden containers at a density of 100 snails $\mathrm{m}^{-2}$ (50 snails per container). The breeding containers were parallelepipedic $(L \times l \times H=1 \mathrm{~m} \times$ $0.5 \mathrm{~m} \times 0.15 \mathrm{~m})$. The interior of the container was covered with a wet foam 'standard mattress' $2 \mathrm{~cm}$ thick. The foam was in its turn covered by a cotton fabric thereby maintaining a high humidity. The lid of each container was covered with a plastic mesh. The containers were positioned randomly on shelves. At the beginning and the end of the experiment, snails were weighed using a Sartorius balance (accuracy of $0.01 \mathrm{mg}$ ) and snail shell lengths measured with an 
Table 1. Diets components determined by chemical analysis (AOAC 1984).

\begin{tabular}{lcccccc}
\hline Diets & Dry matter & Proteins & Total lipids & Mineral matters & Calcium & Crude energy (calg ${ }^{-1}$ ) \\
\hline$R_{1}$ & 40.40 & 17.70 & 2.34 & 8.91 & 0.83 & 2.760 \\
$R_{2}$ & 32.06 & 17.60 & 2.35 & 19.61 & 4.65 & 2.720 \\
$R_{\mathrm{T}}$ & 78.61 & 17.36 & 2.32 & 21.21 & 12.01 & 2.790 \\
$R_{3}$ & 81.07 & 17.48 & 2.36 & 36.36 & 14.02 & 2.785 \\
$R_{4}$ & 81.96 & 17.73 & 2.35 & 41.75 & 16.01 & 2.787 \\
$R_{5}$ & 83.13 & 17.45 & 2.34 & 45 & & 2.725 \\
\hline
\end{tabular}

electronic calliper (accuracy of $1 \mathrm{~mm}$ ). Snails (pilots) with comparable body weight and shell length and exposed to the same photoperiod and diet were used to replace dead snails in order to maintain snail densities. Food was given to the snails ad libitum every 4 days and the containers cleaned. The eggs laid were counted each day and weighed using a balance. From three randomly selected eggs from each laying, we measured the largest and smallest diameter using electronic calliper. Each egg clutch produced was incubated at $26 \pm 1.3^{\circ} \mathrm{C}$ and a relative humidity of $82.9 \pm 1.2 \%$ under a 12 L:12D photoperiod on a substrate of coconut envelopes (Cocos nucifera (Palmaceae)) until hatching (Figure 2). Coconut envelopes were selected because they gives a better hatching rate compared to the humid soil. Juveniles were counted and the hatching success calculated. The snails' growth was followed for 6 months.

\section{Statistical analyses}

Statistical analyses of the data were carried out with the 'SAS ${ }^{\circledR}$ program (1987)'.

Means of the parameters of reproduction were compared using ANOVA (Dagnelie 1975) at 225 days. For mean number of clutch size per diet and mean number of hatched juveniles per clutch, the following model was used:

$$
Y_{i j k}=\mu+R_{i}+B_{i j}+E_{i j k}
$$

where $Y_{i j k}$ is the measured variable, $\mu$ the general average, $R_{i}$ the fixed effect of the diet, $B_{i j}$ the effect of the repetition and $E_{i j k}$ the residual.

For the mean number of egg clutches produced, average weight of an egg, average large diameter and average small diameter of an egg, the following model was used:

$$
Y_{i j}=\mu+R_{i}+E_{i j}
$$

where $Y_{i j}$ is the measured variable, $\mu$ the general average, $R_{i}$ the fixed effect of the diet and $E_{i j}$ the residual.

A Pearson product moment correlation between the various parameters of reproduction was calculated.

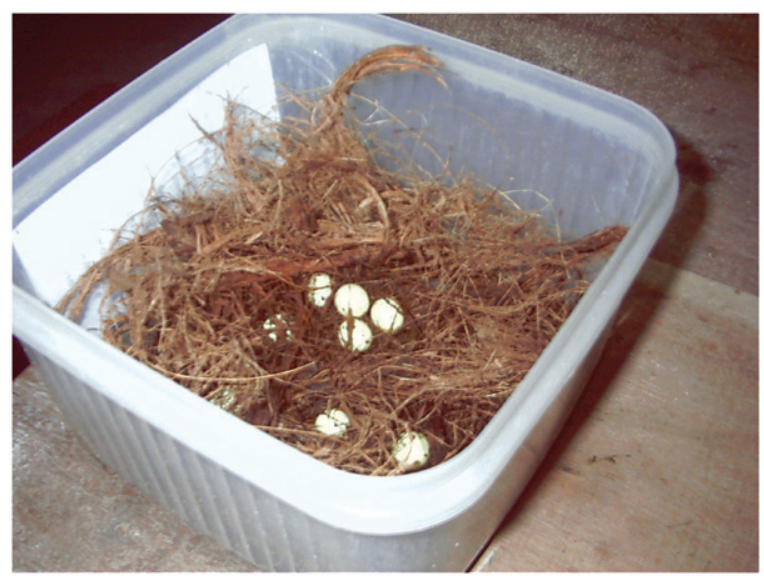

Figure 2. Egg incubation container.

\section{Results}

\section{Chemical analysis of diets}

The chemical analysis of the diets showed that the calcium content of $R_{1}, R_{2}, R_{\mathrm{T}}, R_{3}, R_{4}$ and $R_{5}$ were $0.83 \% ; 4.65 \% ; 6.84 \% ; 12.01 \% ; 14.02 \%$, and $16.01 \%$, respectively. The diets had a $17.50 \%$ average protein content and an average crude energy content of $2.760 \mathrm{cal} \mathrm{g}^{-1}$. The diets $R_{1}$ and $R_{2}$ contained approximately $60 \%$ and $68 \%$ water and had relative low mineral content. Lipid levels did not vary between diets (Table 1).

\section{Reproduction}

For the whole experiment, the total number of clutches produced and hatched clutches were 36 and 19 clutches, respectively. The mean number of egg clutches produced per diet, clutch size and hatching success were 2.77 clutches; 3.38 eggs and $25.27 \%$, respectively. The mean smallest diameter of an egg, largest diameter of an egg, weight of an egg and number of hatched juveniles were $5.23 \mathrm{~mm} ; 6.86 \mathrm{~mm}$; $1.58 \mathrm{~g}$ and 1.16 juveniles, respectively (Table 2 ).

The results showed that the characteristics of the eggs (mean weight, largest diameters and smallest diameters of eggs) increased with the dietary calcium increment (but were not significantly 
Table 2. Effects of diet and dietary calcium on reproductive characteristics in A. ventricosa.

\begin{tabular}{lcccccc}
\hline \multicolumn{7}{c}{ Diets } \\
\hline & $\begin{array}{c}R_{1} \\
(0.83 \% \mathrm{Ca})\end{array}$ & $\begin{array}{c}R_{2} \\
\left(4.6 \%^{\circ} \mathrm{Ca}\right)\end{array}$ & $\begin{array}{c}R_{\mathrm{T}} \\
(06.84 \% \mathrm{Ca})\end{array}$ & $\begin{array}{c}R_{3} \\
(12.01 \% \mathrm{Ca})\end{array}$ & $\begin{array}{c}R_{4} \\
(14.02 \% \mathrm{Ca})\end{array}$ & $\begin{array}{c}R_{5} \\
(16.01 \% \mathrm{Ca})\end{array}$ \\
\hline Mean number of egg clutches & $1.66^{\mathrm{c}}$ & $0.00^{\mathrm{d}}$ & $4.66^{\mathrm{a}}$ & $2.66^{\mathrm{b}}$ & $4.00^{\mathrm{a}}$ & $3.66^{\mathrm{ab}}$ \\
Mean number of clutch size & $4^{\mathrm{b}}$ & $0.00^{\mathrm{d}}$ & $5.5^{\mathrm{a}}$ & $3.33^{\mathrm{c}}$ & $3.16^{\mathrm{c}}$ & $4.33^{\mathrm{b}}$ \\
Mean number of hatched & $1.33^{\mathrm{b}}$ & - & $2.66^{\mathrm{a}}$ & $0.66^{\mathrm{c}}$ & $0.00^{\mathrm{c}}$ & $2.33^{\mathrm{a}}$ \\
$\quad$ juveniles per clutch & $33.33^{\mathrm{c}}$ & - & $45.56^{\mathrm{b}}$ & $19.44^{\mathrm{d}}$ & $0.00^{\mathrm{e}}$ & $53.33^{\mathrm{a}}$ \\
Hatching success $\%)$ & $1.88^{\mathrm{a}}$ & - & $1.90^{\mathrm{a}}$ & $1.88^{\mathrm{a}}$ & $1.91^{\mathrm{a}}$ & $1.94^{\mathrm{a}}$ \\
Average egg weight (g) & $8.06^{\mathrm{a}}$ & - & $8.10^{\mathrm{a}}$ & $8.30^{\mathrm{a}}$ & $8.38^{\mathrm{a}}$ & $8.35^{\mathrm{a}}$ \\
Average largest egg diameter (mm) & $6^{\mathrm{a}}$ & - & $6.10^{\mathrm{a}}$ & $6.21^{\mathrm{a}}$ & $6.53^{\mathrm{a}}$ & $6.53^{\mathrm{a}}$ \\
Average smallest egg diameter (mm) & & & &
\end{tabular}

Note: On each line mean values indexed with different letters are significantly different $(p<0.05)$.

Table 3. Person's product moment correlations between reproduction characters in A. ventricosa.

\begin{tabular}{|c|c|c|c|c|c|c|c|}
\hline & $\begin{array}{l}\text { Mean number } \\
\text { of clutches }\end{array}$ & $\begin{array}{l}\text { Mean number } \\
\text { of clutch size }\end{array}$ & $\begin{array}{l}\text { Mean number } \\
\text { of hatched } \\
\text { juveniles } \\
\text { per clutch }\end{array}$ & $\begin{array}{l}\text { Hatching } \\
\text { success }\end{array}$ & $\begin{array}{l}\text { Mean egg } \\
\text { weight }\end{array}$ & $\begin{array}{l}\text { Largest egg } \\
\text { diameter }\end{array}$ & $\begin{array}{c}\text { Smallest } \\
\text { egg diameter }\end{array}$ \\
\hline Mean number of egg clutches & 1 & & & & & & \\
\hline Mean number of clutch size & 0.434 & 1 & & & & & \\
\hline $\begin{array}{l}\text { Mean number of hatched } \\
\text { juveniles per clutch }\end{array}$ & 0.092 & $0.726^{*}$ & 1 & & & & \\
\hline Hatching success & 0.129 & $0.663 *$ & $0.960 * *$ & 1 & & & \\
\hline Mean egg weight & 0.554 & $0.874 * *$ & 0.425 & 0.454 & 1 & & \\
\hline Largest egg diameter & 0.553 & $0.863^{* *}$ & 0.403 & 0.433 & $0.999 * *$ & 1 & \\
\hline Smallest egg diameter & 0.570 & $0.853 * *$ & 0.410 & 0.446 & $0.997 * *$ & $0.997 * *$ & 1 \\
\hline
\end{tabular}

Note: $* p<0.01 ; * * p<0.001$

different $p>0.05$ ). The mean number of egg clutches produced per diet, the mean number of clutch size and the mean number of hatched juveniles decreased with dietary calcium increment $(p<0.05)$. The snails fed diet $\left(R_{2}\right)$ did not laid during the experiment, whereas those fed diets $R_{1}, R_{\mathrm{T}}, R_{3}$ and $R_{5}$ began to produce egg clutches at the third month. The results (Table 2) showed that the diet $\mathrm{R}_{\mathrm{T}}(6.83 \%$ calcium content $)$ and $R_{5}$ (16.01 calcium content) accelerated sexual maturity and gave the best reproductive outputs. The ANOVA results (Table 2) showed that there was no significant difference $(p>0.05)$ for the mean number of clutches produced per treatment (diet) between diets $R_{\mathrm{T}}, R_{4}$ and $R_{5}$. On the other hand, there was a significant difference $(p<0.05)$ for the mean number of egg clutches per treatment (diet) between diets $R_{1}, R_{2}$ and the other diets. There was a significant different for the mean clutch size between diet $\mathrm{R}_{\mathrm{T}}$ and the diets $R_{1}, R_{2}$, $R_{3}, R_{4}$ and $R_{5}$, but there was no significant difference $(p>0.05)$ for the mean clutch size between diets $R_{3}$ and $R_{4}$ then between diets $R_{1}$ and $R_{5}$. There was a significant difference $(p<0.05)$ for the mean number of hatched juveniles per clutch between diets $R_{\mathrm{T}}, R_{5}$ and diets $R_{3}, R_{4}$ and $R_{1}$. There was a significant difference $(p<0.05)$ for the mean hatching success whatever the diet. There was no significant different $(p>0.05)$ for the mean values of the characteristics of the eggs (weight, largest and smallest diameter) whatever the diet. Table 3 showed that there was a strong positive correlation between the mean clutch size per diet and the mean weight $\left(r^{2}=0.87\right)$, the mean largest diameter $(r=0.86)$ and the mean smallest diameter of an egg $\left(r^{2}=0.85\right)$. There was a strong positive correlation between the mean weight of an egg and the largest diameter $\left(r^{2}=0.99\right)$ and the smallest diameter of an egg $\left(r^{2}=0.99\right)$.

\section{Discussion}

The distribution of these terrestrial snail species in a tropical rainforest, showed that they were present in secondary forest with much human activity, an open canopy and a loose litter. In the sampled forest, there are several preferential microhabitats for Achatinidae: the litter, the soil, the leaves, the herbs, the branches and the dead or living tree trunks. Each species or group of snails has a preferred microhabitat, 
which would reduce dietary competition. Achatina fulica, Archachatina marginata and $A$. ventricosa prefer higher locations (herbs, leaves) (Memel et al. 2008, 2009). The choice of the microhabitat would thus be related to the qualitative and quantitative diversity of food (plants) available. In their natural environment, the Achatinidae snails consume a varied range of wild and cultivated plants. Achatina fulica and A. ventricosa prefer Cecropia peltata and L. aestuans, shrubs of secondary managed forests. The highest rates of phosphorus, sodium, potassium, cellulose, proteins and lipids are observed in these plants and may be responsible for this dietary preference (Agongnikpo et al. 2010). Cook et al. (2000) studying the influence of nutritional status on the feeding behaviour of Deroceras reticulatum (Müller) showed that this field slug, a common pest of agricultural and horticultural crops, is a generalist herbivore with distinct preferences for particular food items. However, the slugs selected food items, when given a choice, containing nutrients that were deficient in earlier diets, even though all the food items contained the same familiar secondary taste chemicals. The results showed that the concentrated diets gave the best reproductive performance when compared to vegetable diets. These results agree with those of Otchoumou et al. (2005b) in A. fulica. In general, animals depend on a large set of essential compounds in their food. A reduced supply of protein and calcium might be critical for the growth, reproduction and survival of herbivorous gastropods. The calcium deficiency could be partly mitigated by the snails' internal calcium storage and reallocation capacity. A depletion of internal calcium reserves adversely affects the entire nutrient metabolism (Wacker and Baur 2004). Therefore, Wacker (2005) showed that differences in diet did not affect shell growth, time to reach adulthood, and reproductive traits such as the number of eggs, dry mass and volume of spermatophores in gastropods. In Achatinidae and particularly A. fulica (Bowdich), spermatogenesis commenced and was completed before the ovogenesis (Ngowsiri et al. 1989). The snails were then male at the end of the spermatogenesis and hermaphrodites at the end of the oogenesis. In the natural environment, young male snails select only adult hermaphroditic individuals as sexual partners. Only hermaphroditic individuals lay after the coupling (Tomiyama 2002). Sexual maturity was reached in A. ventricosa in the natural environment at 12 months of age (Waitkuwait 1989). Our snails (10 months old) were not mature at the beginning of the experiment. The concentrated diets, strongly rich in calcium, proteins and energy particularly the diet $\mathrm{R}_{\mathrm{T}}$, would have stimulated gametogenic maturation and subsequent egg laying. Reproductive development obtained with the vegetable diets was very weak compared to that in snails fed on the concentrated floured diets, which were qualitatively and quantitatively rich in nutrients. The overall results obtained for the clutch size, the dimensions of the eggs and the hatching success were similar to those of other studies (Waitkuwait 1987; Zongo et al. 1990; Otchoumou et al. 2003a; Kouassi et al. 2007a). The mean weights and dimensions of eggs increased with the dietary calcium increment but not significantly, although calcium is important in egg envelope formation (Ireland 1991). Fournié and Chetail (1984) studying the calcium dynamics in land gastropods revealed that calcium is precipitated in the shell, in connective calcium cells which are widely distributed throughout the whole connective tissue, in epithelial calcium cells of the digestive gland, and in the calcium gland cells of the skin and the mantle collar. Calcium is taken up from the external medium via food and by absorption through the foot. To adapt to terrestrial life, these animals allocate appreciable amounts of calcium for their protection and their reproduction. During the egg laying period, a calcium flux occurs through the epithelium of the reproductive tract in order to supply the egg shell and the egg fluids. This egg calcium is taken up by the embryo. The maintenance of a positive calcium balance between its uptake and the loss is due to an important reservoir of easily mobilizable calcium in the form of calcium carbonate. This reservoir consists of the connective calcium cells which are constantly able to accumulate or release calcium as long as calcium is locally available or required. The epithelial calcium cells of the digestive gland are loaded with calcium phosphate and have an essential function in detoxification. However, the fact that the diet $\mathrm{R}_{\mathrm{T}}$ (calcium $6.84 \%$ ) and $R_{5}(16.01 \%$ ) gave the best reproductive development could be explained by their high content in proteins, biogenic salts and especially the calcium. High calcium levels associated with high protein and lipids content play an important role as precursors for signal-transduction involved in the regulation of mating and reproduction. Snails fed a polyunsaturated fatty acid (PUFA)-rich diet showed higher mating activity than snails fed a diet deficient in PUFAs. A depletion of internal PUFA reserves may affect the regulation of mating behaviour, because PUFAs play an important role as precursors for signaltransduction involved in the regulation of mating and reproduction (Wacker 2005). It is clear that dietary calcium influences reproduction in $A$. ventricosa, reproductive indices being elevated with dietary calcium ranging between $6.84 \%$ and $16.01 \%$. Within this range, the $6.84 \%$ calcium gave the greatest number of clutches and, although not significant, the greatest mean number of clutch size and the greatest number of juveniles per clutch. These data indicate that under higher calcium content, reproductive capacities are stimulated, whereas a calcium content $<6.84 \%$ will reduce them, although it has not been shown that low calcium content inhibits the development and the 
maturation of the ovotestis. Finally, the highest dietary calcium was not at the best and even might be toxic. The strong correlations between the mean number of clutches produced and the average number of clutch size, and between the mean number of hatched juveniles per clutch, indicate that conditions which improve the number of eggs laid also causes the ovotestis to be well developed, increase the quantity and quality of eggs laid and improve the rate of hatching. The strong correlations between dimensions of eggs would be due to the allometric relationships phenomenon (Gould 1966).

In this study, we have shown that indoor snail production in Cote d'Ivoire is possible with concentrated floured diets. The reproducers would be fed with diets $6 \%$ to $15 \%$ dietary calcium content and $17.36 \%$; $2.32 \% ; 21.21 \%$ and $2.790 \mathrm{cal} \mathrm{g}^{-1}$ protein, lipid, mineral matter and energy content respectively. However, these results need to be confirmed under large-scale culture conditions.

\section{Acknowledgement}

The authors sincerely thank the Magneraud INRA Hélicicole Unit for its assistance in the formulation and the chemical analysis of diets.

\section{References}

Aboua F. 1995. Proximate analysis and mineral content of two giant African snails consumed in the Ivory Coast. Tropical Science. 35(3):220-222.

Aboua F, Boka K. 1996. Les escargots géants comestibles d'Afrique: quelques aspects physiques et préparation en Côte d'Ivoire. Nature et Faune. 12(4):2-9.

Agongnikpo E, Karamoko M, Otchoumou A. 2010. Diet of the giant African land snail Archachatina marginata, Swainson, 1821 in Ivory Coast: preferences and estimate of damages. Revue d'Ecologie (Terre et Vie). 65:319-330.

AOAC. 1984. In: Horowitz W, editor. Official methods of analysis. Wasington (DC): Association of Official Analytical Chemists.

Cook RT, Bailey SER, McCrohan CR, Nash B, Woodhouse RM. 2000. The influence of nutritional status on the feeding behaviour of the field slug, Deroceras reticulatum (Müller). Animal Behavior. 59:167-176.

Dagnelie, P. 1975. Théories et méthodes statistiques, Applications agronomiques. Les presses agronomiques de Gembloux Ed. 2, 463p.

Ebenso IE. 2002. Consumption and sales of domesticated snails Archachatina marginata in rural southern Nigeria. Tropical Science. 4:185-187.

Ekoué SK, Kuévi-Akué K. 2002. Enquête sur la consommation, la répartition et l'élevage des escargots géants au Togo. Tropicultura. 20:17-22.

Fournié J, Chétail M. 1984. Calcium dynamics in land gastropods. Am Zool. 24:857-870.
Gould SL. 1966. Allometry and size in ontogeny and phylogeny. Biological Review. 41:587-604.

Hodasi JKM. 1979. Life history studies of Achatina achatina (Linné). Journal of Molluscan Studies. 45:228-239.

Ireland MP. 1991. The effect of dietary calcium on growth, shell thickness and tissue calcium distribution in the snail Achatina fulica. Comparative Biochemistry and Physiology. 98(1):111-116.

Kouassi KD, Otchoumou A, Dosso H. 2007a. Effets de l'alimentation sur les performances biologiques chez l'escargot géant africain Archachatina ventricosa (Gould, 1850) en élevage. Livestock Research for Rural Development. Available from: http://www.cipav.org.co./ lrrd19/5/konan19064.htm

Kouassi KD, Otchoumou A, Gnakri D. 2007b. Le commerce des escargots (Achatina achatina), une activité lucrative en Cote d'Ivoire. Livestock Research for Rural Development. Available from: http://www.cipav.org.co./ $\operatorname{lrd} 120 / 4 /$ koua20058.htm

Memel JD, Kouassi KD, Otchoumou A. 2009. Microhabitats des escargots Achatinidae d'une forêt tropicale humide: Le Parc National du Banco (Côte d'Ivoire). Revue d'Ecologie (Terre et Vie). 64:1-17.

Memel JD, Otchoumou A, Dosso H. 2008. Inventaire, potentiel et répartition des escargots terrestres d'une forêt tropicale humide de Côte d'Ivoire: le Parc National du Banco (PNB). Novapex. 9(2-30):101-109.

Ngowsiri U, Sertarugsa P, Sobhon P, Kruatrachue M, Chavadej J, Upatham ES. 1989. Development and seasonal changes in the reproductive system of Achatina fulica. Journal of Science Society of Thailand. 15(4):237-249.

Osemeobo GJ. 1992. Effects of land-use and collection on the decline of African giant snails in Nigeria. Environmental Conservation. 19(2):153-159.

Otchoumou A, Dosso H, Fantodji A. 2003a. The edible African giant snails: fertility of Achatina Achatina (Linné, 1758), Achatina fulica (Bowdich, 1820) and Archachatina ventricosa (Gould, 1850) in humid forest; influence of animal density and photoperiod on fertility in breeding. Bollettino Malacologico. 39:179-184.

Otchoumou A, Dosso H, Fantodji A. 2003b. Elevage comparatif d'escargots juvéniles Achatina achatina (Linné, 1758), Achatina fulica (Bowdich, 1820) et Archachatina ventricosa (Gould, 1850): influence de la densité animale sur la croissance, l'ingestion alimentaire et le taux de mortalité cumulée. Revue Africaine de Santé et Productions Animales. 1(2):146-151.

Otchoumou A, Dupont-Nivet M, Dosso H. 2004a. Les escargots comestibles de Côte d'Ivoire: Effets de quelques plantes, d'aliments concentrés et de la teneur en calcium alimentaire sur la croissance d'Archachatina ventricosa (Gould, 1850) en élevage hors sol en bâtiment. Tropicultura. 22(3):127-133.

Otchoumou A, Dupont-Nivet M, N'da K, Dosso H. 2005a. L'élevage des escargots comestibles Africains: Effets de la qualité du régime et du taux de calcium alimentaires sur les performances de reproduction d'Achatina fulica (Bowdich 1820). Livestock Research for Rural Development. 17(10):118, Available from: http://www.cipav.org.co/ lrrd17/10/otch17118.htm 
Otchoumou A, Dupont-Nivet M, Ocho Anin Atchibri L, Dosso H. 2010. Body proportions and chemical composition of wild and reared edible snails of Ivory Coast. Ital J Food Sci. 22(1):104-110.

Otchoumou A, N'da K, Dosso H, Kouassi KD. 2004b. Inventaire de végétaux sauvages consommés par l'escargot géant africain Archachatina ventricosa (Gould, 1850): préférences alimentaires. Haliotis. 33:13-20.

Otchoumou A, N'da K, Kouassi KD. 2005b. L'élevage des escargots géants comestibles d'Afrique: Inventaire de végétaux sauvages consommés par Achatina achatina (Linné, 1758) et préférences alimentaires. Livestock Research for Rural Devlopment. 17(3):028.

Otchoumou A, Zongo D, Dosso H. 1989-1990. Contribution à l'étude de l'escargot géant africain Achatina achatina (Linné). Annales d'Ecologie, Université Nationale de C.I. 21:31-58.

SAS. 1987. SAS user's guide: statistics, Version 6, Vols. 1 and 2, Cary (NC): SAS Institute.
Takeda N. 1989. Hormonal control of reproduction in land snails. Venus. 48(2):99-139.

Tomiyama K. 2002. Age dependency of sexual role and reproductive ecology in a simultaneously hermaphroditic land snail Achatina fulica (Stylommatophora: Achatinidae). Venus. 60(4):273-283.

Wacker A. 2005. Lipids in the food of a terrestrial snail. Invertebrate Reproduction and Development. 47:205-212.

Wacker A, Baur B. 2004. Effects of protein and calcium concentrations of artificial diets on the growth and survival of the land snail Arianta arbustorum. Invertebrate Reproduction and Development. 46:47-53.

Waitkuwait, E. 1987. Nützungsmöglichkeiten der Westafricanischen Riesenschnecken (Achatinidae) Rapport LACENA/GTZ, 80p.

Zongo D, Coulibaly M, Diambra OH, Adjiri E. 1990. Note sur l'élevage de l'escargot géant africain Achatina achatina (Linné). Nature et Faune. 6(2):32-44. 